\title{
Rewriting History Through Midnight's Children
}

\section{Leila Seyidova}

In Midnight's Children, Salman Rushdie explores the problems of heterogeneity in relation to the hegemonic ideology of nationalism. The novel's protagonist, Saleem Sinai, born at the hour of India's independence in August of 1947, represents India. He tells the story while nearing his thirty-first birthday, and he believes that his body is beginning to literally deteriorate. His loyal companion, Padma, patiently and often skeptically listens to his story, which constitutes the entire novel. Major historical events such as Partition, the violent division of the Indian state into Pakistan and India, drive the plot. "Midnight's Children" refers to those children in India, like Saleem, who were born close to the hour of partition and, as a result, possess magical powers. Saleem's telepathic abilities allow him to enter other people's minds just as the novel demonstrates the state penetrating the citizen's minds to create a nation. Furthermore, Saleem constructs his own version of history through his pickle jars (he owns a pickle factory), which he uses to categorize the different parts of his life, just as Rushdie constructs and organizes India's history through the chapters in the novel. In this essay, I argue that in Midnight's Children, Rushdie rewrites and complicates the idea of history. By transgressing the boundaries between history and fiction, Rushdie reveals the ways in which nationalism relies on the discursive construction of history, meaning that it is constructed from various, rather than a single, sources.

One of the ways Rushdie rewrites history is through the characters' names changing; by altering their names, the characters alter their personal history. One such character, the Brass Monkey, Saleem's younger sister, who later becomes Jamila Singer, is born in India, where she lacks attention from her parents because her brother, Saleem, occupies the spotlight. She eventually grows up to become the most famous singer in Pakistan, adored throughout the country. From her childhood, the Brass Monkey tries to get noticed by her family, in sometimes unusual ways: "She carried her war into the world of footwear, hoping, perhaps, that by burning our shoes she would make us stand still long enough to notice that she was there" (Rushdie 178). Saleem receives most of the family's attention because his birth coincides with the hour of Indian independence, and because he is the first-born son of the family. However, when the Sinai family moves to Pakistan, the Brass Monkey adopts the name Jamila Singer and claims a new identity and history. Jamila's name change reflects her growing importance not only in her family, but in all of Pakistan because through her singing career, she becomes the voice of the nation. When Saleem describes Jamila's success, he says, "Jamila Singer's fame had reached the point at which she could no longer avoid giving a public concert" (Rushdie 374); Jamila's popularity in Pakistan mirrors that of Saleem in India. Her name change demonstrates the instability of her identity - her own and that of a nation. Jamila's character enables Rushdie to show how one person's story can become reflect a country's history.

Jamila's transformation demonstrates how Rushdie rewrites nationalist history. Saleem expresses his disapproval of the artificiality of Pakistan's borders created under Partition when he says, "I have been only the humblest of jugglers - with-facts; and that, in a country where the truth is what it is instructed to be, reality quite literally ceases to exist, so that everything 
becomes possible except what we are told is the case" (Rushdie 389). Pakistan's artificial creation shows how nationalism relies on falsely constructed history to maintain a nation. In Pakistan's case, the false belief in the homogeneity of a Muslim state created by the British causes gaps in national unity that nevertheless continue to divide India and Pakistan. The British, since their colonial rule over India, falsely thought that Pakistan would be a separate nation in which everyone is Muslim. But 'Pakistan' was not even a name the Indian population had ever heard of. Rather, it was the British who believed that the Muslim population that was ruled by the Mughal empire was a nation named Pakistan. This misconception caused the British to divide Pakistan and India on the basis that all Muslims are Pakistanis and all Hindus are Indian, failing to recognize the much more diverse populations of these places. After moving to Pakistan, Saleem falls in love with Jamila, his non-biological sister (Saleem was switched at birth with the family's biological son Shiva); her rejection of these feelings demonstrates the impossibility of Pakistan and India's alliance, just as the sibling's love would be an incestuous one, even if the two are not biologically related. Similar to India and Pakistan's split, Saleem and the Brass Monkey's former unity in India gets destroyed in their move to Pakistan. Through Jamila's and Saleem's problematic relationship, and Jamila's transformation, Rushdie criticizes Partition and shows how nationalism relies on the discursive construction of history.

Saleem's figurative loss of his sister emphasizes Rushdie's point that we risk losing history altogether. In the chapter "How Saleem Achieved Purity," Rushdie writes, "within the house of my aunt's great bitterness my father mother aunt and unborn brother or sister who was only a week away from starting life, [were] all of them all squashed flatter than rice-pancakes [...] wiped clean" (Rushdie 409-410). This passage illustrates the consequence of having our history erased and shows our fear of losing it. In an instant, Saleem loses his entire family and becomes rootless. This example enables Rushdie to demonstrate this fear, because without history, we lose a part of ourselves since we no longer have anything linking us to our origins. In other words, we lose our identity, which explains why Saleem loses his memory in the following chapter where Saleem renames himself as "The Buddha." In that chapter, a bombing occurs and the only thing that survives is Saleem and his spittoon. Saleem does not remember anything, even his own name, which terrifies him, and demonstrates the value of remembering one's individual as well as national history. He refuses to give away his spittoon because it remains the one item of his memory. Saleem's desire to keep the spittoon when he loses his memory symbolizes our fear that whatever we fail to remember ceases to exist.

During the part of the book that depicts the Emergency in 1975-77 declared by Indira Gandhi, where the government had complete control of the state and embarked on program of mass sterilization, Saleem experiences loss in a different way: "I lost something else that day, besides my freedom: bull-dozers swallowed a silver spittoon. Deprived of the last object connecting me to my more tangible, historically-verifiable past" (Rushdie 515). The spittoon disappears with the Emergency, as memory and history do with the Bangladeshi War of Independence in 1971. The spittoon represents Saleem's lineage and it remains as the only object of his personal history. It also plays the role of an anchor and a connector of all the events occurring in the novel. Finally, the spittoon is a kind of receptacle of memories, both personal and nationalist. 


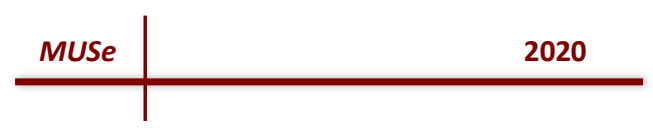

Similarly, the pickle jars from Saleem's factory later join the spittoon as emblems of memory. Saleem separates every chapter of his story into a separate pickle jar. Just as the Sinai family passed down the spittoon, Saleem will pass his pickle jars to his son Aadam Sinai, and his history will live on. Finally, on a larger scale, the book itself, Midnight's Children, constitutes another kind of receptacle of Rushdie's version of history. The multiple receptacles form an interesting parallel between Rushdie telling his story through the novel, Saleem telling his story through the pickle jars, and the spittoon constituting Saleem's and Rushdie's stories. With the spittoon as an allegory of memory and history, Rushdie declares history's discursiveness and its dependence on memory. When Indira Gandhi eliminates the symbol of Saleem's memory, we see the power of the nation to alter historical events.

In contrast to fearing the loss of our history, Rushdie shows our desire to eradicate it. During the Emergency, Indira Gandhi attempts to abolish history by eliminating the Midnight's Children because they do not fit within Indian ethnic, religious, and state nationalism. Rushdie describes the Widow's Hostel where "testicles were removed from sacs, and wombs vanished for ever" (Rushdie 523). Gandhi causes the Midnight's Children's loss of magical talent and their possibility of procreation, with the exception of Shiva's children. Gandhi's actions show that the state can alter historical truth to fit into the truth dictated by the state to maintain a nation. During the Emergency, Gandhi dictated historical truth to create a false appearance of the united Indian nation. However, her seemingly good intentions to eliminate poverty only came about through extreme violence. For instance, Gandhi burned down the magicians' ghetto to exterminate poverty, but she left innocent people homeless. The ghetto was gone, but not the poverty. Gandhi achieved her goals at the expense of the magicians. By emphasizing the Emergency, Rushdie demonstrates not only that nationalism constructs history, but that the nation itself is a fictional construct that relies on citizens' beliefs to become real. In other words, from an Indian nationalist point of view, the Midnight's Children disturb India's homogeneity, since they try to alter history by using their magical powers and go against the political authority's plans, which justifies Gandhi's violence towards them. The Midnight's Children's actions reveal that the state ideology the government used to create an illusion of a united, homogeneous India is false, and that there are many different types of people who live in India and Pakistan, who speak different languages and have differing cultures. The horrific events of the Emergency act as a reminder of the great damage that nationalism caused, which prevails until this day. Gandhi wanted to eradicate the Midnight's Children to erase the memory of their existence and to deepen India's ethnic nationalism.

Rushdie also stresses the danger of amnesia through Gandhi's rise to power. Saleem says in the "The Shadow of the Mosque" chapter, "Today, the papers are talking about the supposed political rebirth of Indira Gandhi [...] Today, perhaps, we are already forgetting, sinking willingly into the insidious clouds of amnesia; but I remember [...] how she- how it happened"' (Rushdie 460-461). The Indian citizens' forgetting of Gandhi's prior brutal and inhumane actions during the Emergency ironically allow her to be praised as an effective leader today. This example shows the state's influence on nationalism and the power it has to infiltrate the citizens' minds. Through Gandhi's rise to power, Rushdie shows memory's importance in constructing history. India's citizens, in glorifying Gandhi today, ignore her past brutal actions. Saleem's shock mentioned in the passage above emphasizes how such historical amnesia can erase history. 
By rewriting history, Rushdie reveals its discursive construction, which poses an interesting question: if history heavily depends on memory, which remains unreliable and changing, what constitutes truth? He answers with a blend between history and fiction. As Saleem says in Book two, “'Memory's truth [...] It selects, eliminates, alters, exaggerates [...] but in the end it creates its own reality"' (Rushdie 253). In other words, memory constitutes truth, but through a blend of history and fiction. Similarly, Saleem says, "Reality is a question of perspective; the further you get from the past, the more concrete and plausible it seems - but as you approach the present, it inevitably seems more and more incredible" and "What's real and what's true aren't necessarily the same" (Rushdie 197). These two statements reveal the potential for history's complicated construction and the state's use of that ambiguous construction for their way of creating nationalism and keeping the state united. This union would be created at the cost of people's individual identity; it would become a melting pot, rather than a country encompassing various individual identities. Similar to India, Saleem embodies a hybrid of history and fiction; he has no roots, his life takes many unexpected and inexplicable turns, and his end remains ambiguous. If Saleem represents India, Rushdie transgresses the boundaries between history and fiction, because some events such as the previously mentioned Emergency remain too difficult to grasp without something beyond pure facts. The mixture of history and fiction in the novel's portrayal of the harsh reality of the Emergency of 1975-77 makes them somewhat tolerable.

In Salman Rushdie's Midnight's Children, Saleem's life, as Mossman writes, "mirrors his nation's life" (1). Saleem represents an allegory of the Indian nation and its impossible unity because India's history and nation remains too vast and diverse to grasp and to unite. Rushdie rewrites history and by blending the lines between history and fiction, showing how nationalism's reliance on discursive construction of history. 


\section{References}

Mossman, Mark. "Salman Rushdie's Midnight's Children: National Narrative as a Liminal Voice." Midwest Quarterly: A Journal of Contemporary Thought (MQ), 1999 Autumn, Vol. 41 Issue 1, pp. 66-78.

Rushdie, Salman. Midnight's Children. Penguin, 1995. 